Louisiana State University

LSU Digital Commons

Faculty Publications

Department of Biological Sciences

$1-1-2007$

\title{
Sex, seasonal, and stress-related variations in elasmobranch corticosterone concentrations
}

Charles A. Manire

Center for Shark Research

L. E.L. Rasmussen

Oregon Health \& Science University

Karen P. Maruska

Florida Institute of Technology

Timothy C. Tricas

Florida Institute of Technology

Follow this and additional works at: https://digitalcommons.Isu.edu/biosci_pubs

\section{Recommended Citation}

Manire, C., Rasmussen, L., Maruska, K., \& Tricas, T. (2007). Sex, seasonal, and stress-related variations in elasmobranch corticosterone concentrations. Comparative Biochemistry and Physiology - A Molecular and Integrative Physiology, 148 (4), 926-935. https://doi.org/10.1016/j.cbpa.2007.09.017

This Article is brought to you for free and open access by the Department of Biological Sciences at LSU Digital Commons. It has been accepted for inclusion in Faculty Publications by an authorized administrator of LSU Digital Commons. For more information, please contact ir@lsu.edu. 


\title{
Sex, seasonal, and stress-related variations in elasmobranch corticosterone concentrations
}

\author{
Charles A. Manire $^{\text {a,* }}$, L.E.L. Rasmussen ${ }^{\text {b }}$, Karen P. Maruska ${ }^{\text {c, } 1}$, Timothy C. Tricas ${ }^{\text {c, } 1}$ \\ ${ }^{a}$ Center for Shark Research, Mote Marine Laboratory, Sarasota, Florida 34236, USA \\ ${ }^{\mathrm{b}}$ Department of Biochemistry and Molecular Biology, OGI School of Science and Engineering, \\ Oregon Health and Science University, Beaverton, Oregon 97006, USA \\ ${ }^{\mathrm{c}}$ Department of Biological Sciences, Florida Institute of Technology, Melbourne, Florida 32901, USA
}

Received 14 May 2007; received in revised form 30 September 2007; accepted 30 September 2007

Available online 5 October 2007

\begin{abstract}
Serum corticosterone was previously studied in numerous elasmobranch fishes (sharks, skates and rays), but the role of this steroid, widespread throughout many taxa, has yet to be defined. The goal of this study was to test whether corticosterone varied in response to acute and chronic capture stress, and across the reproductive cycle in the bonnethead shark, Sphyrna tiburo, and Atlantic stingray, Dasyatis sabina. Serum corticosterone in $S$. tiburo increased following capture and again $24 \mathrm{~h}$ post-capture, possibly caused by interference with $1 \alpha$ hydroxycorticosterone, the primary stress hormone in elasmobranchs. Higher serum concentrations in males compared to females were observed in both species. Variations in corticosterone also occurred during the reproductive cycle in both species. Consistent with other taxa, elevations in male bonnethead sharks and stingrays coincided with peak testicular development and mating. Elevations in female bonnethead sharks occurred from the time of mating through sperm storage into early gestation. In contrast, corticosterone levels in female stingrays were low during their protracted mating season, but elevated through late gestation and parturition. These results indicate that corticosterone has a limited role, if any, in acute and chronic stress associated with capture in S. tiburo, but likely has physiological functions associated with its glucocorticoid properties across the reproductive cycle of both species.
\end{abstract}

(C) 2007 Elsevier Inc. All rights reserved.

Keywords: Corticosterone; Elasmobranch; Reproduction; Shark; Stingray; Stress

\section{Introduction}

The steroid hormone $1 \alpha$-hydroxycorticosterone $(1 \alpha-\mathrm{OHB})$ is considered the major stress hormone in elasmobranchs (Idler and Truscott, 1966, 1967, 1968, 1969; Truscott and Idler, 1968, 1972), but corticosterone (CS) is also found in measurable concentrations in a number of different elasmobranchs from serum (Rasmussen and Gruber, 1990, 1993; Rasmussen and Crow, 1993;

\footnotetext{
* Corresponding author. Mote Marine Laboratory, 1600 Ken Thompson Parkway, Sarasota, Florida 34236, USA. Tel.: +1 941388 4441; fax: +1 941388 4512.

E-mail address: cmanire@mote.org (C.A. Manire).

${ }^{1}$ Present address: Dept. of Zoology \& Hawaii Institute of Marine Biology, University of Hawaii at Manoa, 2538 McCarthy Mall, Edmondson Hall, Honolulu, HI 96822, USA
}

Snelson et al., 1997), and more recently from feces (Karsten, 2003). Although considered primarily a stress hormone in many different taxa, CS has a number of other functions. Like other glucocorticoids, CS can regulate energy balance (King, 1988) and lipogenesis (Berdanier, 1989), promote feeding behavior (Green et al., 1992), stimulate nitrogen metabolism and gluconeogenesis (Vijayan et al., 1996), and inhibit sexual behaviors (Romero, 2002). In birds, CS is linked to migratory activities by increasing feeding and lipogenesis (Meier et al., 1965; Harvey et al., 1984; Berdanier, 1989; Gray et al., 1990; Dallman et al., 1993, 1994; Holberton, 1999). In elasmobranchs, both CS and $1 \alpha$-OHB are produced by the interrenal gland by conversion from progesterone (Simpson and Wright, 1970), but the function of these hormones in reproduction and the response to acute and chronic stressors remain unknown.

Seasonal changes in CS across taxa are often linked to these additional roles in metabolism and reproduction. For example, 
female yellow-pine chipmunks, Tamias amoenus, show seasonal changes in both cortisol and CS, which indicates seasonal regulation of physiologic state, including body mass, energy reserves, and reproductive function (Kenagy and Place, 2000). Likewise, similar seasonal changes were found in other rodents (Armitage, 1991; Boswell et al., 1994), amphibians (Dupont et al., 1979; Licht et al., 1983; Pancak and Taylor, 1983; JolivetJaudet and Ishii, 1985), reptiles (Zerani and Gobbetti, 1983; Schramm et al., 1999), marine teleosts (Vijayan et al., 1996; Sisneros et al., 2004), and human males (Walker et al., 1997). Romero (2002) provided a thorough review of seasonal changes in glucocorticoid concentrations in wild vertebrates that showed glucocorticoids were frequently elevated during the breeding season in free-living reptiles, amphibians, and birds, but not mammals (Hou et al., 2001). Corticosterone seasonal changes also co-vary with testosterone in female bullfrogs (Licht et al., 1983), male stingrays (Snelson et al., 1997) and Galápagos tortoises (Schramm et al., 1999), but are negatively correlated with testosterone concentrations in the crested newt (Zerani and Gobbetti, 1983). However, little is known about seasonal variations or functions of $\mathrm{CS}$ in relation to elasmobranch reproduction.

Sex differences in glucocorticoid concentrations are found in such diverse taxa as mammals, amphibians, reptiles, and fish, e.g., the bullfrog, Rana catesbeiana (Licht et al., 1983), the American alligator, Alligator mississippiensis (Elsey et al., 1990), the loggerhead sea turtle, Caretta caretta (Schwantes and Owens, 1986), the Galápagos tortoise (Schramm et al., 1999), immature whitetip reef sharks, Triaenodon obesus (Rasmussen and Crow, 1993), and Atlantic stingrays, Dasyatis sabina (Snelson et al., 1997). Glucocorticoids can have sexspecific effects on behavior that inhibit the attractiveness of certain mates (Kavaliers and Ossenkoop, 2001) or responses to potential competitors (Wingfield, 1988), but such effects on elasmobranch behavior are unknown.

Glucocorticoids in most vertebrates are secreted in response to various stressors (Sapolsky et al., 2000). Acute stressors, such as capture and handling, often cause increased glucocorticoid concentrations, usually within $2-10 \mathrm{~min}$, depending on the taxa involved (Meka and McCormick, 2005; Romero and Reed, 2005). Chronic stressors, such as maintenance of wild animals in captivity, cause a more prolonged elevation measured in days or longer, that is dependent on the severity of the chronic stress. Elasmobranchs are especially susceptible to both acute and chronic stress associated with capture, handling and maintenance in captivity, but the relationship between corticosterone concentrations and stressors remains unexamined in this vertebrate group.

One goal of this study was to determine whether CS concentrations respond to acute and/or chronic stress associated with capture and maintenance in captivity respectively. In addition, we tested for changes in short-term diurnal and longterm seasonal CS concentrations in captive and wild elasmobranch populations. The bonnethead shark, Sphyrna tiburo, and the Atlantic stingray, D. sabina, were studied because of their high abundance in the study areas, and the established database on their reproductive periodicity, behaviors, and gonadal steroid hormone cycles (Manire et al., 1995, 1999; Maruska et al., 1996; Manire and Rasmussen, 1997; Tricas et al., 2000).

\section{Materials and methods}

The bonnethead shark, S. tiburo, and Atlantic stingray, D. sabina, are common inhabitants in coastal waters of the Gulf of Mexico and southeast U.S. Atlantic coastline. Following are several experiments that were conducted on these two species collected from several populations in Florida.

\subsection{Bonnethead shark capture}

Generally, sharks in this study were captured in set gillnets in coastal or estuarine waters less than $2 \mathrm{~m}$ deep. Some of the same animals were utilized for multiple experiments and multiple studies, including relevant reproductive studies (Manire et al., 1995, 1999; Manire and Rasmussen, 1997). Blood was collected via caudal venipuncture and each shark was measured, weighed, examined to determine sex and reproductive status, and most were subsequently tagged and released. Upon release, each shark was scored on a vitality code based on its post-release behavior. The scores ranged from Condition 1 (condition good, rapid swimming upon release, usually with a vigorous splash) to Condition 5 (moribund and could not be revived, or dead) (Manire et al., 2001; Hueter et al., 2006). The in-the-net time for all sharks ranged from $<1$ min to about $1 \mathrm{~h}$, but precise measurements of that time were determined only in Experiment 1 described below.

\subsection{Experiment 1: Acute stress in the bonnethead shark}

Experiment 1 was designed to test the effects of short-term acute stress on serum CS concentrations in the bonnethead shark. Using the acute stress of capture in a gillnet, blood samples were collected from 18 mature females at known times following capture. To reduce the number of variables and because they were easily accessible, only mature females were tested. For this experiment, nets were set in very shallow water $(<1 \mathrm{~m}$ deep) to enable personnel to observe sharks splashing as they encountered the net from a distance adequate enough to not influence the sharks. As a shark was observed to hit the net, the time was noted and the boat was quickly moved into position to retrieve the shark. As soon as the personnel reached the shark, a blood sample was collected before the shark was removed from the net. The time was noted at the end of the venipuncture and sharks were treated as above. Most were quickly released, although a few were maintained aboard the boat, either for subsequent blood sampling or for transport for some of the following experiments.

Sharks collected at other times for which time in-the-net could not be observed were assigned a vitality score as described above. It was assumed that stress increases with length of time in the net resulting in a higher vitality score (worse condition). This provided a rough estimate of how long an animal was in the net and allowed for the determination of differences in serum CS concentrations of 62 male and 83 female sharks captured at in-the-net times of up to $60 \mathrm{~min}$ although the exact time was unknown. 


\subsection{Experiment 2: Chronic stress of captivity in the bonnethead shark}

To test the effects of chronic captivity stress on serum CS concentrations, five bonnethead sharks were captured and transported to Mote Marine Laboratory in sealed plastic bags that contained chilled sea water saturated with oxygen. These sharks were subsequently maintained in 5500-18,500 L tanks with flow-through or recirculated filtered sea water systems. Serial blood samples were collected from each individual on Day 0 (immediately after capture in the field) and days 1, 3, 7, and 30 in captivity. This allowed dual measurements of CS concentrations during capture and transport (acute stress) and maintenance in captivity (chronic stress). Some of the sharks from this experiment had been previously used in Experiment 1 above.

\subsection{Experiment 3: Seasonal changes in CS concentrations in captive bonnethead sharks}

Sera from five mature captive sharks from Experiment 2 (2 males and 3 females) were collected monthly for $8-13$ months and analyzed for CS. Captive female sharks were maintained with mature males for the duration of this experiment. Fresh mating wounds were observed on the female sharks during the same season that mating was observed among wild populations in the same area (Manire et al., 1995). Therefore, it was assumed that the reproductive cycles of the captive shark group were similar to wild sharks from the same area.

\subsection{Experiment 4: Diurnal changes in CS concentrations in the bonnethead shark}

Mature female bonnethead sharks $(n=37)$ were collected at Coquina Key in Tampa Bay $\left(27^{\circ} 42^{\prime} \mathrm{N}, 82^{\circ} 37^{\prime} \mathrm{W}\right)$ throughout a $24 \mathrm{~h}$ time period during 26-27 April 1999. A minimum of three sharks were collected in each $3 \mathrm{~h}$ period starting at midnight and all sharks were in the early pregnancy stage (Manire et al., 1995). Blood was collected as soon as the animals were brought aboard the boat, usually within $1 \mathrm{~min}$. All animals collected during that time period were tagged and released.

\subsection{Experiment 5: Seasonal cycles and sex differences in the bonnethead shark}

Blood samples from wild sharks (196 females and 185 males) at different maturational and reproductive stages were collected from three different sites that included Florida Bay $\left(24^{\circ} 50^{\prime} \mathrm{N}, 80^{\circ} 49^{\prime} \mathrm{W}\right)$ in the Florida Keys, Anclote Key near Tampa Bay $\left(28^{\circ} 13^{\prime} \mathrm{N}, 82^{\circ} 50^{\prime} \mathrm{W}\right)$ on the central Florida Gulf coast, and Apalachicola Bay $\left(29^{\circ} 40^{\prime} \mathrm{N}, 85^{\circ} 12^{\prime} \mathrm{W}\right)$ in the Florida Panhandle in conjunction with a study of contaminants (Gelsleichter et al., 2005). Sharks were collected in gillnets and blood was collected as soon as the animals were brought aboard the boat, usually within $3 \mathrm{~min}$. All sharks from this study were sacrificed and stages of reproduction and maturation were determined.

\subsection{Experiment 6: Seasonal cycles and sex differences in the Atlantic stingray}

As part of a comprehensive study on the reproduction and steroid cycles of Atlantic stingrays (Kajiura and Tricas, 1996; Maruska et al., 1996; Kajiura et al., 2000; Tricas et al., 2000), sera from a population (231 mature females and 163 mature males) in the southern Banana River on the east coast of central Florida $\left(28^{\circ} 12.5^{\prime} \mathrm{N}, 80^{\circ} 38.3^{\prime} \mathrm{W}\right)$ were sampled. Ten mature stingrays of each sex (males $>19 \mathrm{~cm}$ disk width [DW], females $>22 \mathrm{~cm}$ DW) were collected on or near the 15th of each month from August 1992 through September 1995 for females and through January 1994 for males. Stingrays were captured with hand nets or beach seines, immediately transported to shore, euthanized and sampled to reduce the influence of stress on blood hormone levels.

\subsection{Serum analysis}

Blood was collected from bonnethead sharks via caudal venipuncture, transferred to sterile blood tubes, and immediately placed on ice where it was allowed to clot for 6-12 h. Blood samples from stingrays were taken by direct cardiac puncture, transferred to centrifuge tubes, and placed on ice for $3-6 \mathrm{~h}$ to clot. Blood then was centrifuged at 1286-1800 g for $5 \mathrm{~min}$ and the serum was removed and stored at $-70{ }^{\circ} \mathrm{C}$ until analyzed.

Radioimmunoassay (RIA) analysis was utilized for determination of corticosterone concentration in the elasmobranch serum. Two different volumes of serum $(25 \mu \mathrm{l}$ and $75 \mu \mathrm{l})$ were extracted with diethyl ether and then analyzed by RIA directly (using the antiserum reported in Gruenewald et al., 1992). The two different volumes were used to insure that at least one of the values fell on the linear portion of the curve. The reported value is the average of the two estimates when both volumes fell on the linear portion of the curve (as most did) or the single concentration was used when only one fell on it. In the current study, the percent recovery for corticosterone was $89 \%$, sensitivity was $3 \mathrm{pg} / \mathrm{mL}$, intraassay coefficient of variation was $6.9 \%$ and interassay variation was less than $5 \%$. This methodology was utilized in a number of studies (Rasmussen and Gruber, 1990, 1993; Rasmussen and Crow, 1993; Snelson et al., 1997) knowing that the degree of non-parallelism discernible in the RIA of CS (after the standard diethyl ether extraction without further purification) indicated the presence of interference by $1 \alpha$-OHB. Corticosterone concentrations were calculated based on the quantitation reported by Honn and Chavin (1978) that $100 \%$ of the elasmobranch corticosterone (low in total amount) and $11.5 \%$ of the $1 \alpha-\mathrm{OHB}$ reacts with corticosterone antiserum using the methodology reported by Kime (1977). All concentration values are reported in $\mathrm{pg} / \mathrm{mL}$. Direct analysis of $1 \alpha-\mathrm{OHB}$ was not possible as multiple attempts to purify the steroid were unsuccessful (Manire, unpublished data).

\subsection{Statistics}

CS concentration data did not meet the assumptions required for parametric statistics and could not be normalized by transformation, thus non-parametric tests were used for all 


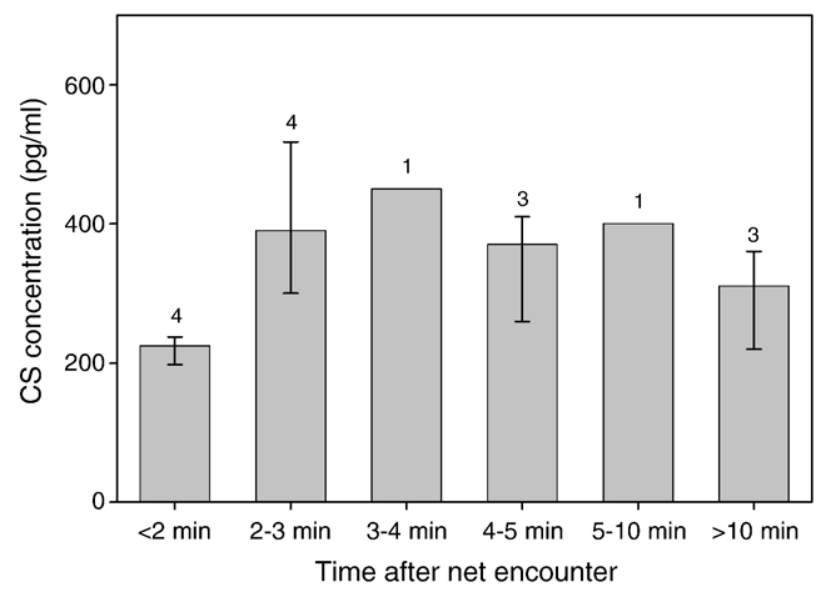

Fig. 1. Median corticosterone concentrations (25th-75th percentile) in mature female $S$. tiburo at known times following gillnet encounter. The data did not fit the assumptions for parametric statistics and therefore is presented as nonparametric. There was no significant difference in CS concentrations across the first 15 min following gillnet encounter, but levels were higher at 2-3 min compared to the prior time frame. Sample size is indicated above bars.

comparisons and data are reported as medians and percentiles (25th-75th). The non-parametric Kruskal-Wallis one-way ANOVA on Ranks was used to compare CS concentrations in all groups. If one-way ANOVA results were significant $(P<0.05)$, the non-parametric Dunn's Pairwise Multiple Comparison Procedure was utilized to determine treatment differences. For male bonnethead sharks, stages were compared by month of the year as in Manire and Rasmussen (1997). For female bonnethead sharks, data were first compared by month, as in the males, and then in eight different reproductive stages as in Manire et al. (1995). For the Atlantic stingray, stages in both sexes were compared by month of the year as in Tricas et al. (2000).

\section{Results}

\subsection{Sex and species differences}

When data were grouped by sex and species, there were significant differences in both comparisons. Male sharks had the highest overall CS concentrations $(n=149, \bar{x}=2302 \mathrm{pg} / \mathrm{mL})$ and female stingrays had the lowest $(n=231, \bar{x}=174 \mathrm{pg} / \mathrm{mL})$. CS levels in female bonnethead sharks $(n=146, \bar{x}=1191 \mathrm{pg} /$ $\mathrm{mL})$ were significantly lower than that of males $(P<0.05)$, but significantly higher than stingrays of both sexes $(P<0.05)$. Male stingrays $(n=163, \bar{x}=451 \mathrm{pg} / \mathrm{mL})$ were significantly lower than $S$. tiburo of both sexes $(P<0.05)$ and significantly higher than female $D$. sabina $(P<0.05)$.

\subsection{Experiment 1: Acute stress in the bonnethead shark}

No significant difference was found in CS concentration over the first 15 min following gillnet encounter for the bonnethead shark (Fig. 1) (KW one-way ANOVA, $P=0.104)$. However, sharks sampled at 2-3 min after encountering the net had consistently higher CS concentrations than animals sampled earlier.
For the sharks scored by vitality code, animals were grouped as males or females prior to comparison because of sex differences in CS concentrations. There were significant differences in CS concentration across vitality codes (KW one-way ANOVA, $P=0.043$ in males; $P=0.005$ in females), but pairwise comparison failed to detect a difference between the sharks released in good condition (minimally stressed, Conditions 1-2) and those released in poor condition (more stressed, Fig. 2). There was high variability among individuals within each vitality code.

\subsection{Experiment 2: Chronic stress of captivity in the bonnethead shark}

When CS concentrations were examined in sharks captured in the wild and transported for captive maintenance, there were inadequate numbers to compare statistically, but in all cases CS concentrations were somewhat higher at $24 \mathrm{~h}$ than immediately following capture (Fig. 3), and most concentrations returned to initial levels within 3-7 days. In addition, males appeared to show a more pronounced increase in CS concentrations at $24 \mathrm{~h}$ compared to females.
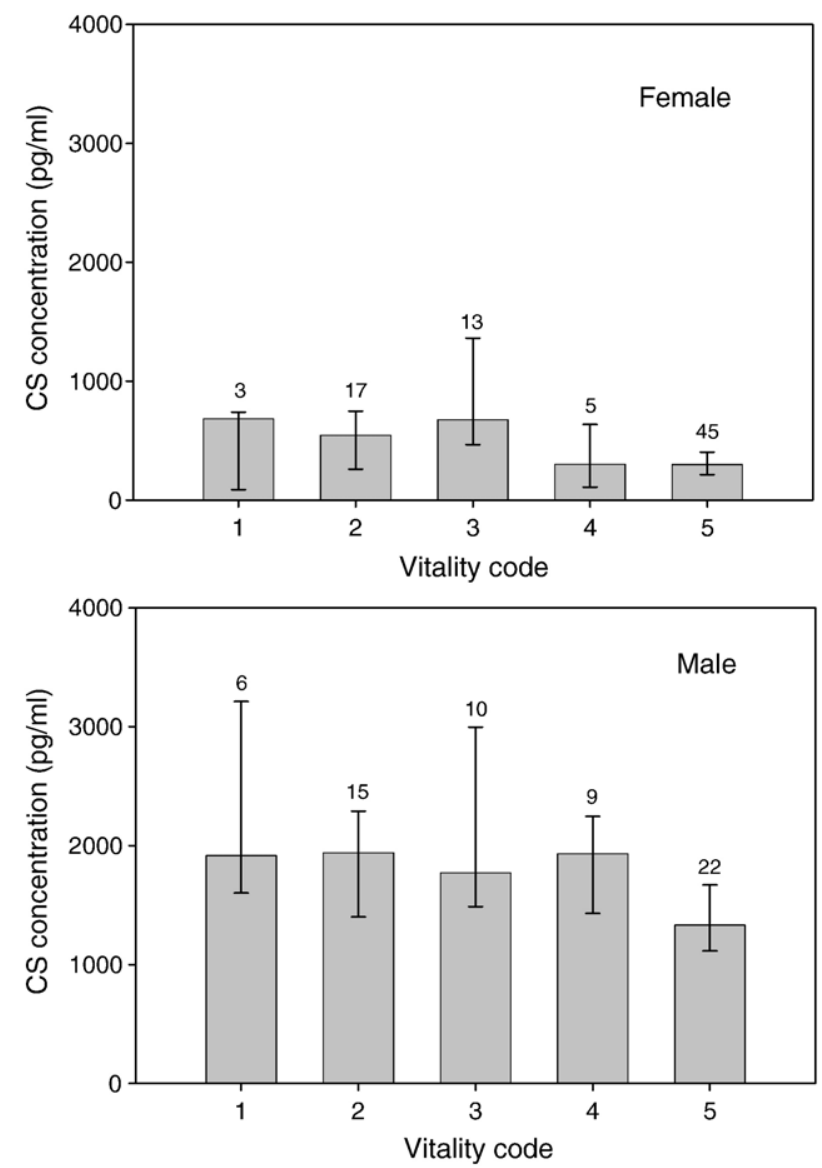

Fig. 2. Median corticosterone concentrations (25th-75th percentile) in the bonnethead shark, S. tiburo, by vitality code at time of release. The data did not fit the assumptions for parametric statistics and therefore is presented as nonparametric. There was no difference in CS concentration among sharks released in good (1-2) versus poor (3-5) condition. See text for full explanation of vitality codes. Sample size is indicated above bars. 


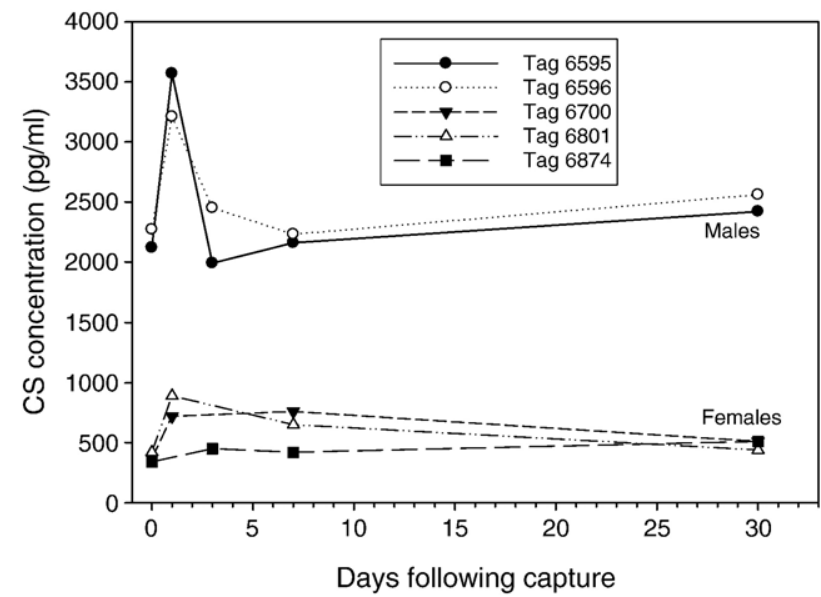

Fig. 3. Corticosterone concentrations in individual captive bonnethead sharks, $S$. tiburo, during the first month following capture and transport. CS concentrations were elevated at $24 \mathrm{~h}$ post-capture and most returned to initial levels within $3-$ 7 days. Tags 6595 and 6596 are mature males and all others are mature females.

\subsection{Experiment 3: Seasonal changes in CS concentrations in captive bonnethead sharks}

Seasonal variations in bonnethead shark CS levels were evident starting at about 1 week in captivity. These variations (Fig. 4) were very similar to the cycles observed in wild sharks (Experiment 5 below). Although not tested statistically, starting at $72 \mathrm{~h}$ post-capture, no differences in CS concentrations were obvious between the wild and captive sharks from the same area. In captivity, female CS concentrations increased at mating time (Oct.-Nov.) and remained high through sperm storage until ovulation (Nov.-Mar.). In males, concentrations increased gradually throughout the summer during spermatogenesis (June-Aug.) and peaked in Sept.-Oct., just prior to mating.

\subsection{Experiment 4: Diurnal changes in CS concentrations in the bonnethead shark}

There were no significant differences in CS concentrations over the $24 \mathrm{~h}$ sampling period in bonnetheads (KW one-way ANOVA, $P=0.716$ ) (Fig. 5). However, the highest median concentrations occurred during the time period from 1500$1759 \mathrm{~h}$ and the lowest from 0900-1159 h.

\subsection{Experiment 5: Seasonal cycles and maturational differences in the bonnethead shark}

CS concentrations in sharks differed among sex and stage of maturity. Immature females had significantly lower CS concentrations (KW one-way ANOVA, $P<0.05$ ) compared to mature females and all males, and mature females had lower CS concentrations $(P<0.05)$ than all males. There was no significant difference between immature and mature males.

Serum CS concentrations also showed seasonal variations in mature male bonnethead sharks. Significant peak concentrations were found in August and October (KW one-way ANOVA, $P<0.05$ ) with a smaller peak in March that was not statistically significant (Fig. 6). The significant peaks occurred just prior to mating (Oct.-Nov.).

CS concentrations also differed by month as well as across reproductive stage in mature female bonnethead sharks. When compared by month, CS was significantly elevated in November, January, and March-May (KW one-way ANOVA, $P<0.05$, Fig. 6). Compared by reproductive stage, significant elevations in CS concentrations occurred from mating through early pregnancy (KW one-way ANOVA, $P<0.05$ ), with the exception of the post-ovulatory period. The lowest concentrations occurred during the post-partum stage (Fig. 7).

\subsection{Experiment 6: Seasonal cycles and sex differences in the Atlantic stingray}

Serum CS in the Atlantic stingray showed seasonal variations related to the reproductive cycle, but these differed among sexes. $\mathrm{CS}$ concentrations were elevated (KW one-way ANOVA, $P<0.05)$ in females from June through September, the period of late pregnancy, parturition, and post-partum stages (Fig. 8). Low female corticosterone levels were found from October through March during the mating period. In contrast, male
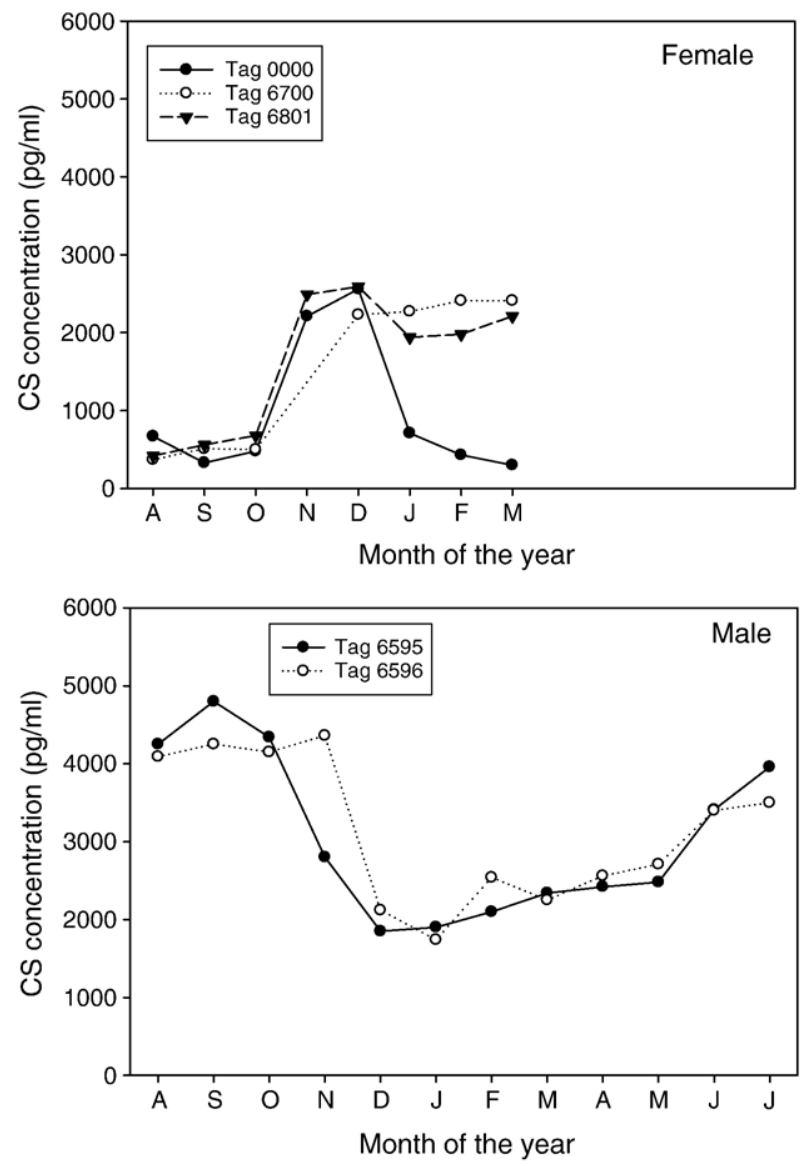

Fig. 4. Seasonal cycles of corticosterone concentrations in individual mature bonnethead sharks, S. tiburo, maintained in captivity. Female CS concentrations increased at mating (Nov.) and remained high through sperm storage and ovulation (Dec.-Mar.). Male CS levels increased gradually throughout the summer (May-Sept.) and peaked in Sept.-Oct. just prior to mating. 


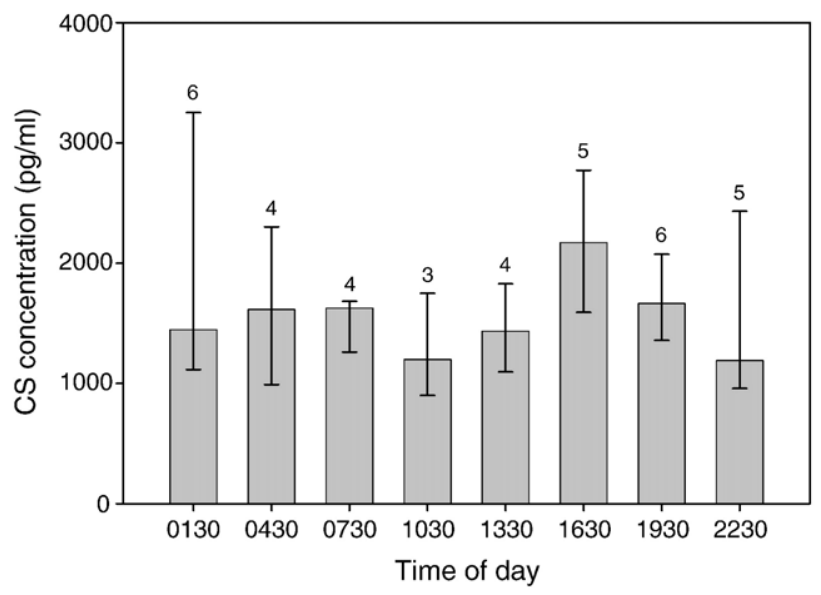

Fig. 5. Median corticosterone concentrations (25th-75th percentile) in mature female bonnethead sharks, $S$. tiburo, captured at $3 \mathrm{~h}$ intervals over a $24 \mathrm{~h}$ period. The data did not fit the assumptions for parametric statistics and therefore is presented as non-parametric. Highest CS levels occurred from 1500-1759 h, but there was no diurnal difference in CS concentrations over the $24 \mathrm{~h}$ sampling period. Sample size is indicated above bars.

stingray CS concentrations were elevated during the mating season from Aug. - Feb. and were lower during non-mating from Apr--July (KW one-way ANOVA, $P<0.05$ ) (Fig. 8).

\section{Discussion}

The current study showed differences in CS concentrations among sexes, stage of maturity, and species. Additionally, seasonal changes were seen in both male and female bonnethead sharks and Atlantic stingrays, most notable was the elevated CS levels in males of both species during mating. Short-term diurnal changes in bonnetheads were not found. Finally, no significant changes in CS levels were found associated with acute stress and only minor changes with chronic stress of captivity.

\subsection{Corticosterone and stress}

Previous studies have shown the hormone $1 \alpha$-hydroxycorticosterone to be the major stress hormone in elasmobranchs (Idler and Truscott, 1966, 1967, 1968, 1969; Truscott and Idler, 1968, 1972); however, CS is also found in measurable concentrations in numerous elasmobranch species (Rasmussen and Gruber, 1990, 1993; Rasmussen and Crow, 1993; Snelson et al., 1997). For most other taxa, glucocorticoid concentrations start to increase in a $2-3$ min window after a noxious stimulus (Sapolsky et al., 2000; Wingfield and Romero, 2001), except in some reptiles where this increase is not detectable for $10 \mathrm{~min}$ (Tyrrell and Cree, 1998). The current study shows elevated CS levels in bonnethead sharks $24 \mathrm{~h}$ post-capture. The concentrations return to baseline levels by $72 \mathrm{~h}$ post-capture, if not sooner. The timing of these concentration changes indicates that CS may have some function in the stress response of S. tiburo, but the magnitude of increase in concentration is inadequate for a primary stress hormone. It is more likely that interference by $1 \alpha$-OHB caused the small elevation, as it is expected that a large elevation in $1 \alpha-\mathrm{OHB}$ would cause a slight increase in the measured CS concentration. Repeated attempts to produce a pure $1 \alpha-\mathrm{OHB}$ were unsuccessful, so development of an assay for $1 \alpha-\mathrm{OHB}$ is not possible given our current technology. Thus future studies are needed to resolve the relative roles of CS and $1 \alpha$-OHB in the response of elasmobranchs to capture and handling stressors.

Rasmussen and Crow (1993) suggested that monitoring CS concentrations in captive individuals could provide information regarding health or stress of the population. However, to be a useful predictor of stress, sex and seasonal variations in CS concentrations must also be taken into account. A better approach would be to develop an assay for $1 \alpha-\mathrm{OHB}$, which has proven very difficult as the published method for synthesizing the hormone (Kime, 1975) does not produce a pure steroid (Manire, unpublished data).
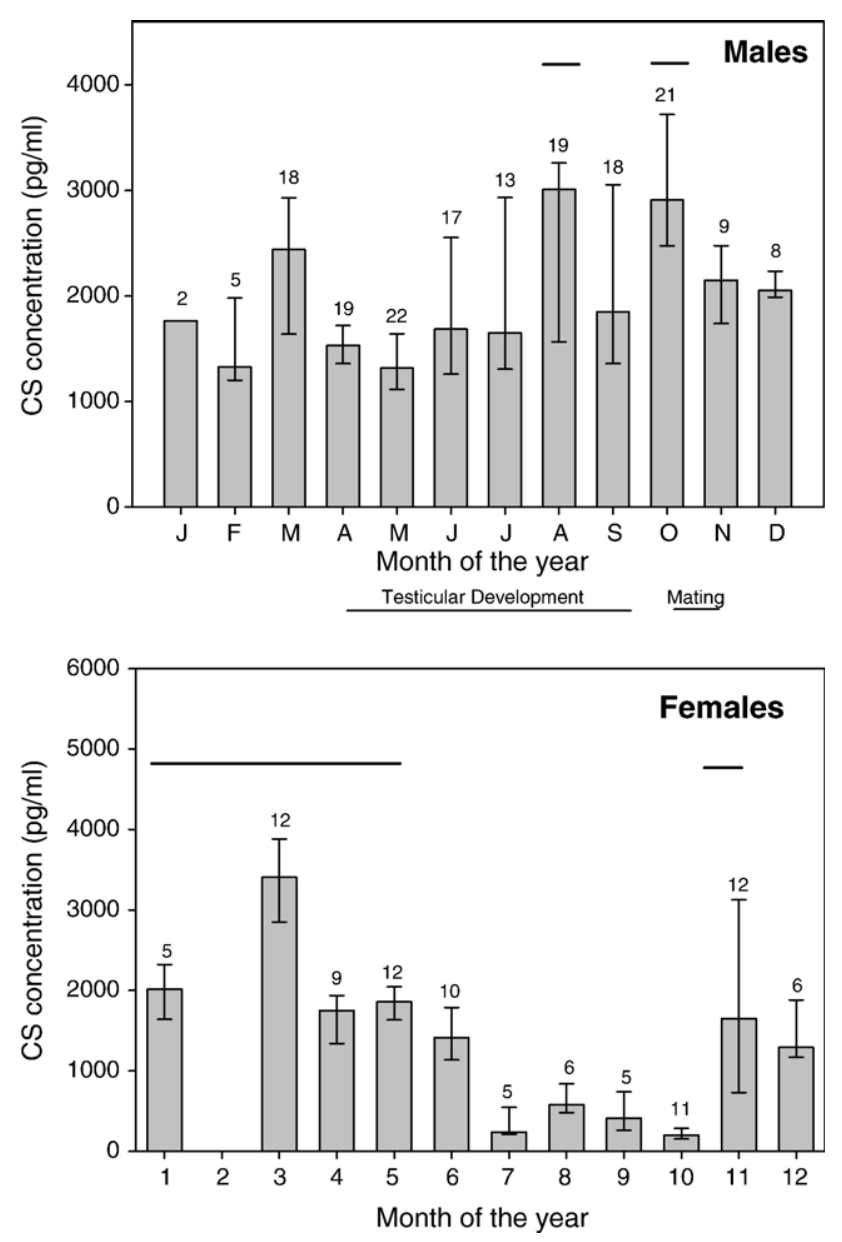

Fig. 6. Seasonal cycle of median corticosterone concentrations (25th-75th percentile) in mature male and female bonnethead sharks, S. tiburo. The data did not fit the assumptions for parametric statistics and therefore is presented as nonparametric. For males, data are by month of capture. CS concentrations peak in August and October just prior to mating, with a second peak in March. See Manire and Rasmussen (1997) for complete explanation of reproductive stages. Bars below graph indicate times of testicular development and mating. For seasonal comparisons, female data are presented here by month of capture. Significant CS peaks occur in November and again in January through May (KW one-way ANOVA, $P<0.05$ ). 


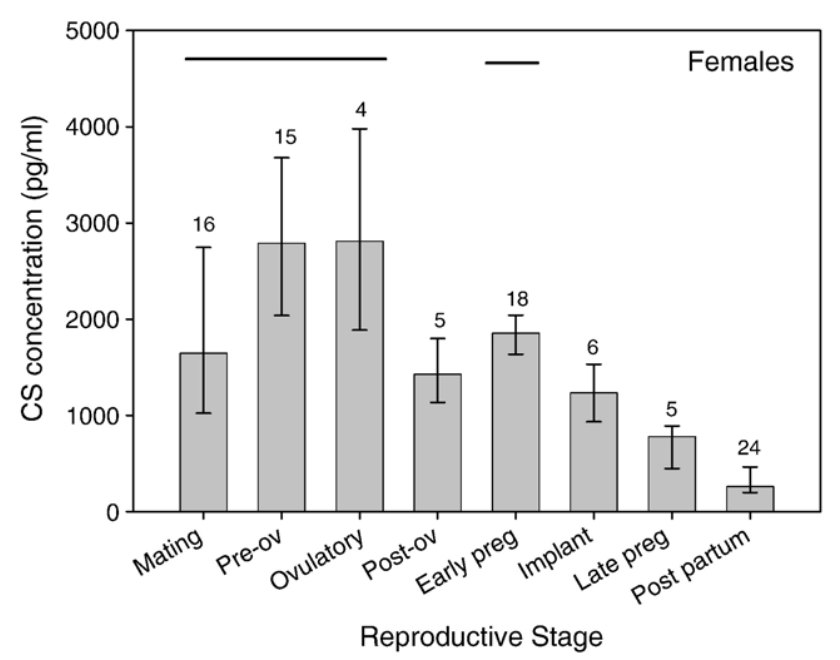

Fig. 7. Seasonal cycle of median corticosterone concentrations (25th-75th percentile) in mature female bonnethead sharks, S. tiburo, presented by stage of reproduction. The data did not fit the assumptions for parametric statistics and therefore is presented as non-parametric. Data are by eight different stages of reproduction. See Manire et al. (1995) for complete explanation of reproductive stages. CS concentrations were elevated from mating through early pregnancy, with the exception of the pre-ovulatory time, and were lowest during postpartum. Sample size is indicated above bars. Lines above bars indicate groups that were significantly different from remaining groups (KW one-way ANOVA, $P<0.05)$.

\subsection{Corticosterone seasonal cycles}

An analysis of seasonal changes in glucocorticoids in over 100 species of free-living (wild) reptiles, amphibians, birds, and mammals (Romero, 2002) demonstrated that the majority of species in all four taxa exhibited seasonal CS changes; however the causes were unknown. The data did show that in almost all taxa except mammals, glucocorticoid concentrations tended to be highest during the breeding season. Seasonal cycles in corticosteroid concentrations are often related to their glucocorticoid activities (Romero, 2002). In birds, glucocorticoid concentrations are elevated prior to migration and appear to increase feeding behavior and lipogenesis (Holberton, 1999). In yellow-pine chipmunks, peak concentrations occur in late lactation, and indicate seasonal regulation of the physiologic state (Kenagy and Place, 2000). A similar role of CS as a glucocorticoid is postulated for the bonnethead shark and Atlantic stingray elasmobranchs used in the current study.

As in other taxa studied, corticosterone seasonal changes were found to co-vary with testosterone in male and female bonnethead sharks. Male bonnethead sharks undergo testicular development and spermatogenesis from late spring until its peak in late summer (Parsons and Grier, 1992), with mating in mid-autumn (Manire and Rasmussen, 1997) followed by migration out of the area until they return early the following spring. CS in male bonnetheads increases in concentration from June to October, and is correlated with testicular development, spermatogenesis, and the peak growing season. Highest levels are observed around mating and prior to migration. Testosterone, dihydrotestosterone, and progesterone also increase in the same time frame, but peak two months prior to the highest CS concentrations (Manire and Rasmussen,
1997). Thus CS levels in male bonnethead sharks are correlated with specific physiological and behavioral reproductive activities as shown for other taxa (Romero, 2002).

In female bonnethead sharks, ovulation takes place in early spring, followed by a 4.5 month gestation with parturition in late summer (Parsons, 1993), then mating again in mid-autumn and migration out of the area from late autumn until early spring (Manire et al., 1995). Highest CS concentrations in these females correlate with mating, vitellogenesis, sperm storage, migration, and early pregnancy. Strikingly, the lowest CS concentrations in female bonnetheads coincide with highest CS concentrations in the males. Peak CS concentrations in females, however, coincide with elevations in $17 \beta$-estradiol, progesterone, testosterone, and dihydrotestosterone.

The Atlantic stingray is common to coastal regions of the Atlantic and Gulf of Mexico, but is primarily estuarine in its
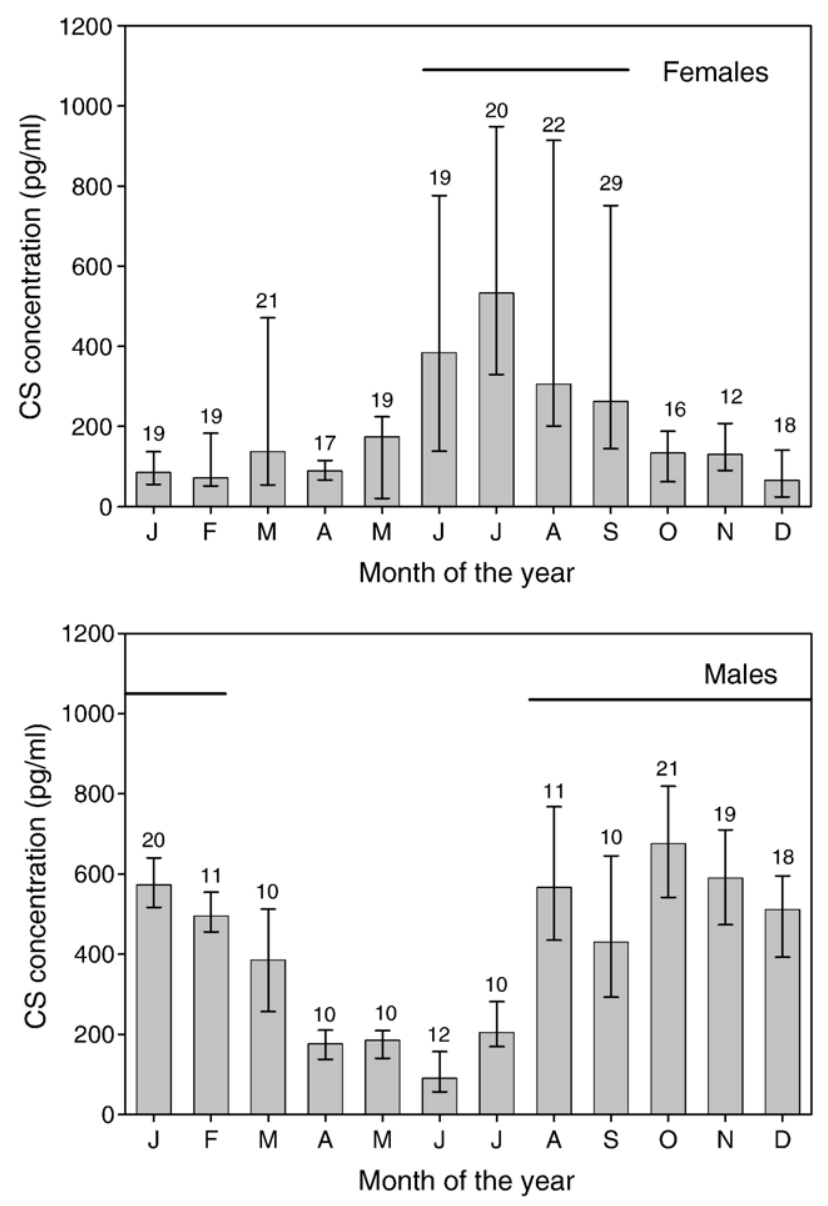

Fig. 8. Median corticosterone concentrations in the Atlantic stingray, D. sabina, by month of capture. The data did not fit the assumptions for parametric statistics and therefore are presented as non-parametric. CS concentrations in females were elevated during late pregnancy, parturition and post-partum stages from June through September, and low during the protracted mating season from October-March. In contrast, male CS concentrations were elevated during spermatogenesis and the protracted mating season from August-February and lowest in June during the non-mating period. See Tricas et al. (2000) for complete explanation of reproductive cycle. Bars show medians and 25th-75th quartiles. Sample size is indicated above bars. Lines above bars indicate groups that were significantly different from remaining groups (KW one-way ANOVA, $P<0.05)$. 
distribution throughout the year. Ova development in female stingrays occurs over a 5-6 month period from September through March with ovulation among females in a narrow synchronous time window in March or April (Maruska et al., 1996). This period of ova development coincides with a protracted and consistent 7-month mating season from October through April in which females in the population constantly bear fresh mating scars (Kajiura et al., 2000) and evidence of insemination (Maruska et al., 1996). Another difference from the bonnethead is that Atlantic stingray populations do not show migratory behavior away from coastal mating areas, rather females gestate for about 3 months and undergo parturition in the estuary in July-August. Thus, the elevated CS concentrations observed for female stingrays in June through September correlate with late pregnancy, parturition, and post-partum stages, and also with elevated serum 17 $\beta$-estradiol and progesterone concentrations that peak in July (Tricas et al., 2000). This differs from female $S$. tiburo that show low CS levels during late pregnancy and post-partum periods. Furthermore, the protracted and traumatic mating activity of Atlantic stingrays is not correlated with elevated CS in females. These species differences in CS among females may be due to different physiological demands associated with divergent reproductive strategies and behavior among sharks and rays, or variations in environmental conditions/stressors between habitats.

The CS levels did correlate with testosterone levels and mating activities in the male stingrays in this study. Male stingrays in this population undergo testicular development in late summer with maximum gonad size attained in October followed by peak sperm production in January (Maruska et al., 1996). Elevated CS concentrations during August-February in males coincide with testis development, mating activity and also elevated testosterone, dihydrotestosterone, 17ß-estradiol, and progesterone, all of which reach significant peaks in October (Tricas et al., 2000). However, unlike females, elevated male stingray CS occurs when male-male competition and courtship/ mating with females is strongest in this high-density reproductive population. Thus similar to the bonnethead shark, CS levels in male Atlantic stingrays are also correlated with high levels of mating behavior.

In a study of Atlantic stingrays in freshwater Lake Monroe, Florida, Snelson et al. (1997) observed no elevations in CS in females and found peak CS in males in March, much later than in the current study. The authors did not report when mating occurred, but it is likely to occur at the same time as that reported for the estuarine population (Maruska et al., 1996). In the Lake Monroe study, male CS peaked concurrently with testosterone and dihydrotestosterone, but not $17 \beta$-estradiol or progesterone. However, the freshwater Lake Monroe stingray population differs from the estuarine population in many aspects of seasonal steroidogenic activity that may be related to the different physiological requirements and environments. Tricas et al. (2000) found other temporal and steroidal differences between these two populations that are beyond the scope of this paper.

Although elasmobranchs have not received much attention regarding seasonal changes in glucocorticoids, the current study indicates that a pattern similar to that in other taxa may be present in the bonnethead shark and the Atlantic stingray. In both species, the concentrations of CS are the highest in males prior to and during mating activities. However, future studies are needed to examine proximate mechanisms of seasonal CS variations in these and other elasmobranch species.

At concentrations attained during acute or chronic stress, glucocorticoids are known to inhibit gonadal hormone release (Sapolsky et al., 2000), but exogenous testosterone leads to increased glucocorticoid concentrations in birds (Schoech et al., 1999). This indicates that interactions between these hormones are complex. It is possible that gonadal androgens may be important physiological regulators of seasonal changes in glucocorticoids (Romero, 2002). The link between testosterone, dihydrotestosterone, and CS concentrations in the two elasmobranch species in this study may also indicate this regulation of seasonal changes in glucocorticoids by gonadal androgens. Future studies of binding proteins and tissue sensitivity are necessary to further understand why these seasonal changes occur.

\subsection{Diurnal cycle in corticosterone concentrations}

Several studies show diurnal (circadian) cycles in glucocorticoid concentrations in a variety of taxa. Recent studies have found a relationship between circadian rhythm of blood levels of melatonin and corticosterone (Barriga et al., 2002; Jessop et al., 2002). A CS peak was found in the late afternoon in the crested newt (Zerani and Gobbetti, 1983), American toads (Pancak and Taylor, 1983), and the desert iguana (Chan and Callard, 1972), but in captive loggerhead sea turtles the peak occurred in the morning (Schwantes and Owens, 1986). Dupont et al. (1979) found the diurnal peak in CS to follow a seasonal cycle, with the peak at midnight in May, at $1900 \mathrm{~h}$ in July, and at $0800 \mathrm{~h}$ in November in the edible frog. In the current study, the diurnal variation was not statistically significant, but highest concentrations occurred in late afternoon, similar to several other studies (Zerani and Gobbetti, 1983; Pancak and Taylor, 1983; Chan and Callard, 1972). It is possible that a larger sample size would show the peak to be significant. Results of the current study may also have been influenced by the pregnancy state of all sharks at the time of the experiment.

\subsection{Sex differences in corticosterone concentrations}

Differences in CS concentration between males and females have been demonstrated in reptiles (Schwantes and Owens, 1986; Elsey et al., 1990; Schramm et al., 1999; Amey and Whittier, 2000; Ott et al., 2000) and elasmobranchs (Rasmussen and Crow, 1993; Snelson et al., 1997) as well as in mammals (Boswell et al., 1994; Kenagy et al., 1999). Neither sex has consistently higher concentrations across taxa, possibly related to different life history strategies that reflect sex-specific physiological responses to stress. Another possibility is that the hormone serves different physiological functions unrelated to the stress response. Both elasmobranch species in the current study showed higher concentrations in males, but the reason for this difference is unknown. 


\subsection{Conclusions}

The present study demonstrates both a short- and long-term corticosterone response to capture and handling stress in an elasmobranch species. However, future studies are needed to examine the relationship between CS and stress because corticosterone appears not to be the major stress hormone in elasmobranchs and elevations observed in the present study may be due to interference by $1 \alpha$-OHB rather than actual elevations in $\mathrm{CS}$. Serum CS concentrations are sexually dimorphic and vary seasonally in both the shark and stingray with highest concentrations during or around breeding (mating) season. It is possible that this seasonal pattern is related to temporal changes in androgen concentrations in these two species or some other physiological character related to reproductive activity. Additional studies are necessary for a complete understanding of the role of corticosterone in elasmobranchs and a study of seasonal change and response to stress of $1 \alpha$-hydroxycorticosterone will begin if a method to isolate or synthesize $1 \alpha-\mathrm{OHB}$ can be found.

\section{Acknowledgements}

We wish to express our deep sense of loss for the passing of our colleague, friend, and co-author, Dr. Bets Rasmussen. She was a true comparative endocrinologist with diverse interests, and a great inspiration to us and her many other peers. We thank John Tyminski, Jim Gelsleichter and numerous undergraduate college interns that assisted with the capture of the animals, maintenance of sharks in captivity, and handling of the samples during the various studies, David Hess for assistance with the RIAs, Bud Bodine plus the staff from Steraloids, Inc. for attempting to produce $1 \alpha-\mathrm{OHB}$, and Florida Tech students (particularly Joe Sisneros) for helping with animal collections. This project was partially supported by funding from NOAA/NMFS to R. Hueter, MML Center for Shark Research as well as funding from US EPA to C. Manire. Although the research described in this article has been funded in part by the United States Environmental Protection Agency through Grant \# R826128-01-0, it has not been subjected to the Agency's required peer and policy review and therefore does not necessarily reflect the views of the Agency and no official endorsement should be inferred.

\section{References}

Amey, A.P., Whittier, J.M., 2000. Seasonal patterns of plasma steroid hormones in males and females of the bearded dragon lizard, Pogona barbata. Gen. Comp. Endocrinol. 117, 335-342.

Armitage, K., 1991. Factors affecting corticosteroid concentrations in yellowbellied marmots. Comp. Biochem. Physiol. 98A, 47-54.

Barriga, C., Marchena, J.M., Lea, R.W., Harvey, S., Rodriguez, A.B., 2002. Effects of stress and dexamethasone treatment on circadian rhythms of melatonin and corticosterone in ring dove (Streptopelia risoria). Mol. Cell. Biochem. 232, 27-31.

Berdanier, C.D., 1989. Role of glucocorticoids in the regulation of lipogenesis. Fed. Amer. Soc. Exp. Biol. J. 3, 2179-2183.

Boswell, T., Woods, S.C., Kenagy, G.J., 1994. Seasonal changes in body mass, insulin, and glucocorticoids of free-living golden-mantled ground squirrels. Gen. Comp. Endocrinol. 96, 339-346.

Chan, S.W.C., Callard, I.P., 1972. Circadian rhythm in the secretion of corticosterone by the desert iguana, Dipsosaurus dorsalis. Gen. Comp. Endocrinol. 18, 565-568.
Dallman, M.F., Strack, A.M., Akana, S.F., Bradbury, M.J., Hanson, E.S., Scribner, K.A., Smith, M., 1993. Feast or famine: critical role of glucocorticoids with insulin in daily energy flow. Frontiers in Neuroendocrinol. 14, 303-347.

Dallman, M.F., Akana, S.F., Levin, N., Walker, C-D., Bradbury, M.J., Suemaru, S., Scribner, K.S., 1994. Corticosteroids and the control of function in the hypothalamo-pituitary-adrenal (HPA) axis. In: de Kloet, E.R., Asmitia, E.C., Landfield, P.W. (Eds.), Brain Corticosteroid Receptors: Studies on the Mechanism, Function, and Neurotoxicity of Corticosteroid Action, vol. 746. Annals of the New York Academy of Sciences, New York, pp. 22-32.

Dupont, W., Bourgeois, P., Reinberg, A., Vaillant, R., 1979. Circannual and circadian rhythms in the concentration of corticosterone in the plasma of the edible frog (Rana esculenta L). J. Endocrinol. 80, 117-125.

Elsey, R.M., Joanen, T., McNease, J., Lance, V., 1990. Stress and plasma corticosterone levels in the American alligator — relationships with stocking density and nesting success. Comp. Biochem. Physiol. 95A, 55-63.

Gelsleichter, J., Manire, C.A., Szabo, N.J., Cortés, E., Carlson, J., LombardiCarlson, L., 2005. Organochlorine concentrations in bonnethead sharks (Sphyrna tiburo) from four Florida estuaries. Arch. Environ. Contam. Toxicol. 48, 474-483.

Gray, J.M., Yarian, D., Ramenofsky, M., 1990. Corticosterone, foraging behavior, and metabolism in dark-eyed junco, Junco hyemalis. Gen. Comp. Endocrinol. 79, 375-384.

Green, P.K., Wilkinson, C.W., Woods, S.C., 1992. Intraventricular corticosterone increases the rate of body weight gain in underweight adrenalectomized rats. Endocrinol. 130, 269-275.

Gruenewald, D.A., Hess, D.L., Wilkinson, C.W., Matsumoto, A.M., 1992. Excessive testicular progesterone secretion in male Fischer 344 rats: a potential cause of age-related gonadotropin suppression and confounding variable in aging studies. J. Gerontol. 42B, 164-170.

Harvey, S., Phillips, J.G., Rees, A., Hall, T.R., 1984. Stress and adrenal function. J. Exp. Zool. 232, 633-645.

Holberton, R.L., 1999. Changes in patterns of corticosterone secretion concurrent with migratory fattening in a neotropical migratory bird. Gen. Comp. Endocrinol. 116, 49-58.

Honn, K.V., Chavin, W., 1978. In vitro tropic action of ACTH upon adrenocortical cyclic nucleotide (cAMP, cGMP) production and corticosterone output in blue (Prionace glauca Linnaeus) and mako (Isurus oxyrinchus Rafinesque) sharks. Gen. Comp. Endocrinol. 36, 161-169.

Hou, Y., Han, X., Suzuki, Y., 2001. Annual changes in plasma levels of cortisol and sex steroid hormones in male rainbow trout, Oncorhynchus mykiss. Chin. J. Ocean. Limnol. 19, 217-221.

Hueter, R.E., Manire, C.A., Tyminski, J.P., Hoenig, J.M., Hepworth, D.A., 2006. Assessing mortality of released or discarded fish using a logistic model of relative survival derived from tagging data. Trans. Amer. Fish. Soc. 135, 500-508.

Idler, D.R., Truscott, B., 1966. $1 \alpha$-hydroxycorticosterone from cartilaginous fish: a new adrenal steroid in blood. J. Fish. Res. Bd. Can. 23, 615-619.

Idler, D.R., Truscott, B., 1967. $1 \alpha$-hydroxycorticosterone: synthesis in vitro and properties of an interrenal steroid in the blood of cartilaginous fish (Genus Raja). Steroids 9, 457-477.

Idler, D.R., Truscott, B., 1968. 1 $\alpha$-hydroxycorticosterone and testosterone in body fluids of a cartilaginous fish (Raja radiata). J. Endocrinol. 42, 165-166.

Idler, D.R., Truscott, B., 1969. Production of $1 \alpha$-hydroxycorticosterone in vivo and in vitro by elasmobranchs. Gen. Comp. Endocrinol. 2 (Supple.), 325-330.

Jessop, T.S., Limpus, C.J., Whittier, J.M., 2002. Nocturnal activity in the green sea turtle alters daily profiles of melatonin and corticosterone. Horm. Behav. 41, 357-365.

Jolivet-Jaudet, G., Ishii, S., 1985. Annual changes in interrenal function in the Japanese toad, Bufo japonicus. In: Follett, B.K., Ishii, S., Chandola, A. (Eds.), The Endocrine System and the Environment. Springer-Verlag, Berlin, pp. 45-53.

Kajiura, S.M., Sebastian, A., Tricas, T.C., 2000. Dermal bite wounds as indicators of reproductive seasonality and behaviour in the Atlantic stingray, Dasyatis sabina. Environ. Biol. Fish. 58, 23-31.

Kajiura, S.M., Tricas, T.C., 1996. Seasonal dynamics of dental sexual dimorphism in the Atlantic stingray, Dasyatis sabina. J. Exp. Biol. 199, 2297-2306. 
Karsten, A.H., 2003. Fecal corticosterone assessment in the epaulette shark, Hemiscyllium ocellatum. J. Exp. Zool. 299A, 188-196.

Kavaliers, M., Ossenkopp, K.P., 2001. Corticosterone rapidly reduces male odor preferences in female mice. Neuroreport 12, 2999-3002.

Kenagy, G.J., Place, N.J., 2000. Seasonal changes in plasma glucocorticosteroids of free-living female yellow-pine chipmunks: effects of reproduction and capture and handling. Gen. Comp. Endocrinol. 117, 189-199.

Kenagy, G.J., Place, N.J., Veloso, C., 1999. Relation of glucocorticosteroids and testosterone to the annual cycle of free-living degus in semiarid central Chile. Gen. Comp. Endocrinol. 115, 236-243.

Kime, D.E., 1975. Synthesis of 1a-hydroxycorticosterone. J. Chem. Soc., Perkin $1,2371-2374$

Kime, D.E., 1977. Measurement of 1a-hydroxycorticosterone and other corticosteroids in elasmobranch plasma by radioimmunoassay. Gen. Comp. Endocrinol. 33, 344-351.

King, B.M., 1988. Glucocorticoids and hypothalamic obesity. Neurosci. Biobehav. Rev. 12, 29-37.

Licht, P., McCreery, B.R., Barnes, R., Pang, R., 1983. Seasonal and stress related changes in plasma gonadotropins, sex steroids and corticosterone in the bullfrog, Rana catesbeiana. Gen. Comp. Endocrinol. 50, 124-145.

Manire, C., Hueter, R., Hull, E., Spieler, R., 2001. Serological changes associated with gill-net capture and restraint in three species of sharks. Trans. Amer. Fish. Soc. 130, 1038-1048.

Manire, C.A., Rasmussen, L.E.L., 1997. Serum concentrations of steroid hormones in the mature male bonnethead shark, Sphyrna tiburo. Gen. Comp. Endocrinol. 107, 414-420.

Manire, C.A., Rasmussen, L.E.L., Hess, D.L., Hueter, R.E., 1995. Serum steroid hormones and the reproductive cycle of the female bonnethead shark, Sphyrna tiburo. Gen. Comp. Endocrinol. 97, 366-376.

Manire, C.A., Rasmussen, L.E.L., Gross, T.S., 1999. Serum steroid hormones including 11-ketotestosterone, 11-ketoandrostenedione, and dihydroprogesterone in juvenile and adult bonnethead sharks, Sphyrna tiburo. J. Exp. Zool. 284, 595-603.

Maruska, K.P., Cowie, E.G., Tricas, T.C., 1996. Periodic gonadal activity and protracted mating in elasmobranch fishes. J. Exp. Zool. 276, 219-232.

Meier, A.H., Farner, D.S., King, J.R., 1965. A possible endocrine basis for migratory behavior in the white-crowned sparrow, Zonotrichia leucophrys gambelii. Anim. Behav. 13, 453-465.

Meka, J.M., McCormick, S.D., 2005. Physiological response of wild rainbow trout to angling: impact of angling duration, fish size, body condition, and temperature. Fish. Res. 72, 311-322 (Amsterdam).

Ott, J.A., Mendonca, M.T., Guyer, C., Michener, W.K., 2000. Seasonal changes in sex and adrenal steroid hormones of gopher tortoises (Gopherus polyphemus). Gen. Comp. Endocrinol. 117, 299-312.

Pancak, M.K., Taylor, D.H., 1983. Seasonal and daily plasma corticosterone rhythms in American toads Bufo americanus. Gen. Comp. Endocrinol. 50, $490-497$.

Parsons, G.R., 1993. Geographic variation in reproduction between two populations of the bonnethead shark, Sphyrna tiburo. Exp. Biol. Fish. 38, $25-35$.

Parsons, G.R., Grier, H., 1992. Seasonal changes in shark testicular structure and spermatogenesis. J. Exp. Zool. 261, 173-184.

Rasmussen, L.E.L., Crow, G.L., 1993. Serum corticosterone concentrations in immature captive whitetip reef sharks, Triaenodon obesus. J. Exp. Zool. 267, 283-287.

Rasmussen, L.E.L., Gruber, S.H., 1990. Serum levels of circulating steroid hormones in free-ranging carcharhinoid sharks. NOAA Tech. Rept. 90, 143-155.
Rasmussen, L.E.L., Gruber, S.H., 1993. Serum concentrations of reproductively-related circulating steroid hormones in the free-ranging lemon shark, Negaprion brevirostris. Environ. Biol. Fishes 38, 167-174.

Romero, L.M., 2002. Seasonal changes in plasma glucocorticoid concentrations in free-living vertebrates. Gen. Comp. Endocrinol. 128, 1-24.

Romero, L.M., Reed, J.M., 2005. Collecting baseline corticosterone samples in the field: is under 3 min good enough? Comp. Biochem. Physiol. Part A 140, 73-79.

Sapolsky, R.M., Romero, L.M., Munck, A.U., 2000. How do glucocorticoids influence stress responses? Integrating permissive, suppressive, stimulatory, and preparative actions. Endocrine Rev. 21, 55-89.

Schoech, S.J., Ketterson, E.D., Nolan, V., 1999. Exogenous testosterone and the adrenocortical response in dark-eyed juncos. Auk 116, 64-72.

Schramm, B.G., Casares, M., Lance, V.A., 1999. Steroid levels and reproductive cycle of the Galápagos tortoise, Geochelone nigra, living under seminatural conditions on Santa Cruz Island (Galápagos). Gen. Comp. Endocrinol. 114, $108-120$

Schwantes, N.L., Owens, D., 1986. Serum corticosterone titers in two sea turtle species, Caretta caretta and Lepidochelys olivacea, during nesting, mating, and hatching. Amer. Zoologist 26, 26A.

Simpson, T.H., Wright, R.S., 1970. Synthesis of corticosteroids by the interrenal gland of selachian elasmobranch fish. J. Endocrinol. 46, 261-268.

Sisneros, J.A., Forlano, P.M., Knapp, R., Bass, A.H., 2004. Seasonal variation of steroid hormone levels in an intertidal-nesting fish, the vocal plainfin midshipman. Gen. Comp. Endocrinol. 136, 101-116.

Snelson Jr., F.F., Rasmussen, L.E.L., Johnson, M.R., Hess, D.L., 1997. Serum concentrations of steroid hormones during reproduction in the Atlantic stingray, Dasyatis sabina. Gen. Comp. Endocrinol. 108, 67-79.

Tricas, T.C., Maruska, K.P., Rasmussen, L.E.L., 2000. Annual cycles of steroid hormone production, gonad development, and reproductive behavior in the Atlantic stingray. Gen. Comp. Endocrinol. 118, 209-225.

Truscott, B., Idler, D.R., 1968. The widespread occurrence of a corticosteroid $1 \alpha$-hydroxylase in the interrenals of Elasmobranchii. J. Endocrinol. 40, $515-526$.

Truscott, B., Idler, D.R., 1972. Corticosteroids in plasma of elasmobranchs. Comp. Biochem. Physiol. 42A, 41-50.

Tyrrell, C.L., Cree, A., 1998. Relationships between corticosterone concentration and season, time of day and confinement in a wild reptile (tuatara, Sphenodon punctatus). Gen. Comp. Endorinol. 110, 97-108.

Vijayan, M.M., Mommsen, T.P., Glémet, H.C., Moon, T.W., 1996. Metabolic effects of cortisol treatment in a marine teleost, the sea raven. J. Exp. Biol. 199, 1509-1514.

Walker, B.R., Best, R., Noon, J.P., Watt, G.C.M., Webb, D.J., 1997. Seasonal variation in glucocorticoid activity in healthy men. J. Clin. Endocrinol. Metab. 82, 4015-4019.

Wingfield, J.C., 1988. Changes in reproductive function of free-living birds in direct response to environmental perturbations. In: Stetson, M.H. (Ed.), Processing of Environmental Information in Vertebrates. Springer-Verlag, Berlin, pp. 121-148.

Wingfield, J.C., Romero, L.M., 2001. Adrenocortical responses to stress and their modulation in free-living vertebrates. In: McEwen, B.S., Goodman, H.M. (Eds.), Handbook of Physiology, vol. 4. Oxford University Press, New York, pp. 211-234.

Zerani, M., Gobbetti, M., 1993. Corticosterone during the annual reproductive cycle and in sexual behavior in the crested newt, Triturus carnifex. Horm. Behav. 27, 29-37. 